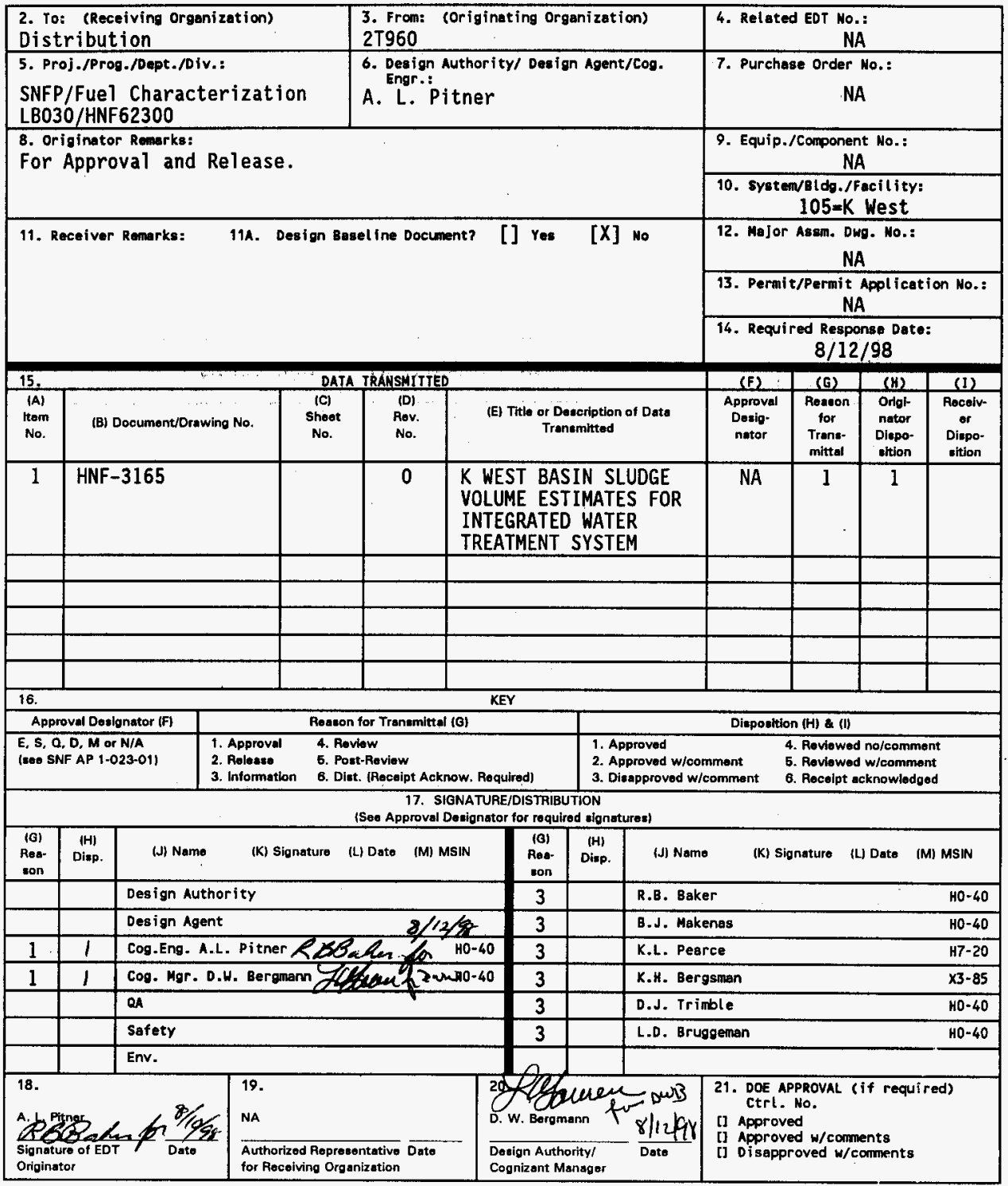




\section{K WEST BASIN SLUDGE VOLUME ESTIMATES FOR INTEGRATED WATER TREATMENT SYSTEM}

A.L. Pitner

Duke Engineering Services Hanford, Inc., Richland, WA 99352

U.S. Department of Energy Contract DE-AC06-96RL13200

$\begin{array}{lll}\text { EDT/ECN: } & 620805 & \text { UC: UC 2070 } \\ \text { Org Code: } & \text { 2T960 } & \text { Charge Code: } \\ \text { B\&R Code: } & \text { EW7040000 } & \text { Total Pages: } 4\end{array}$

Key Words: Sludge, fuel condition, fuel storage, fuel processing

Abstract: Estimates were made of the volume of sludge expected 1) from Integrated Process Strategy (IPS) processing of the fuel and 2) in the fuel storage canisters in $K$ West Basin. These were based on visual observations of fuel element condition in the basin and laboratory measurements of canister sludge density. These estimates, made in early 1997, are reviewed and the basic assumptions used discussed.

TRADEMARK DISCLAIMER. Reference herein to any specific comercial product, process, or service by trede nime, tredenark, menufecturer, or otherwise, does not necesearily constitute or iaply its endorsement, recommendetion, or favor ing by the united states Goverment or amy agency thereof or its contractors or subcontractors.

Printed in the United States of Anerics. To obtain copies of this document, contact: Docusent Control services, P.0. BoX 950, Mailstop H6-08, Richland UA 99352, Phone (509) 372-2420; Fax (509) $376-4989$.
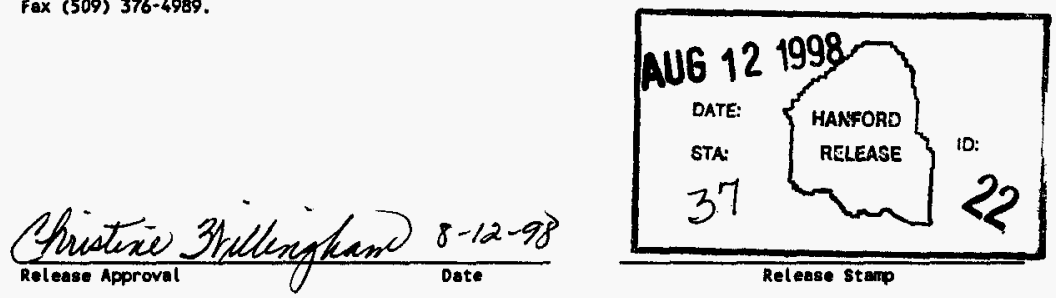

\section{Approved for Public Release}


HNF-3165, Rev. 0

\section{$K$ WEST BASIN SLUDGE VOLUME ESTIMATES FOR \\ INTEGRATED WATER TREATMENT SYSTEM}

January 1997

Originator:

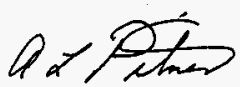

A. L. Pitner

Peer Review:

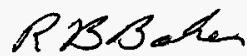

R. B. Baker

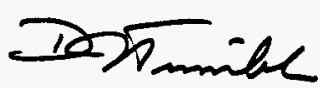

D. J. Trimble 


\section{Purpose}

An estimate was made to project the volume of sludge expected from Integrated Process Strategy (IPS) processing of the fuel and in the fuel storage canisters in $K$ West Basin to support the Integrated Water Treatment System (ITWS). A nominal "Working Estimate" as well as an upper level "Working Bound" were developed.

\section{Summary of Results and Conclusions}

The Working Estimate of the sludge volume for ITWS design basis is 3000 liter, and the Working Bound is 6200 liter.

\section{Assumptions}

The inventory of spent fuel stored in $K$ West Basin is comparable to that stored in $K$ East Basin, as is the number of canisters containing the fuel. In the recent visual examination campaign conducted to inspect approximately $250 \mathrm{~K}$ West selected fuel assemblies, the level of damage found was comparable to that seen in similar $K$ East fuel examinations. Thus, it is expected that the level of sludge generated during IPS processing of the $K$ West fuel should be comparable to that estimated for the $K$ East fuel. Accordingly, the working estimate of fuel sludge expected to be generated during IPS processing of $K$ West fuel is 1300 liter, and the bounding estimate is 3200 liter (Reference 2).

The estimated canister sludge inventory for the $K$ West Basin was provided in Reference 1. The best estimate derived for the as-settled volume of sludge in the $K$ West fuel storage canisters was 1700 liter, while the upper bound estimate was 3000 liter.

\section{Sources}

References: (1) Internal Memo, D. J. Trimble to D. S. Takasumi," $K$ West Basin Canister Sludge Inventory," dated January 26, 1997.

(2) Internal Memo, A. L. Pitner to D. S. Takasumi, "K East Basin Sludge Volume Estimates for Integrated Water Treatment System," dated January 23, 1997. 
HNF-3165, Rev. 0

\title{
Calculation
}

The projected total sludge inventory for IWTS planning activities is the sum of the IPS fuel processing and canister sludge estimates.

\author{
Working Estimate \\ 1300 liter (IPS) +1700 liter (canisters) $=3000$ liter \\ Working Bound \\ 3200 liter (IPS) +3000 1iter (canisters) $=62001$ iter
}

